DOI: 10.17707/AgricultForest.65.1.15

\author{
Melisa LJUŠA*, Hamid ČUSTOVIĆ ${ }^{1}$
}

\title{
AGRICULTURAL LAND USE AND LAND LOSSES IN BOSNIA AND HERZEGOVINA IN THE PERIOD 1961-2018
}

\begin{abstract}
SUMMARY
In Bosnia and Herzegovina (BiH) there are no available data on permanent losses of agricultural land and it is evident that all the research and professional and scientific literature still uses the information of annual land loss in the amount of 3,000 ha which, according to the available references, has been in use since 1977 (Resulović, 1977-2010).

The subject of this scientific research is to investigate changes in the use of agricultural land in $\mathrm{BiH}$, sectoral policies and factors affecting these changes as well as the quality of official data on land and land use change. Analyzed as part of this research were three sets of data: statistical data (1961-1991), cadastral records (1973-1991) and CORINE data on land cover changes (2000-2018).

Researches have shown that trends in changes in total agricultural land by all categories of use were not linear and were considerably affected by the socioeconomic development and sectoral policies. This study has shown that total agricultural land, according to statistical records from 1961-1991, was reduced by 101,222 ha $(3,374 \mathrm{ha} / \mathrm{yr})$. Within the category of arable land, the biggest permanent losses were recorded in cropland and gardens, amounting to 207,823 ha or $6,927 \mathrm{ha} / \mathrm{yr}$, while in some other categories within the arable land an increase was recorded. According to cadastral records for the period 1973-1991, the total decrease of agricultural land amounts to 58,186 ha (3,232 ha/yr). According to CORINE data, the reduction of agricultural land in the period 20002018 is 14,152 ha or $786 \mathrm{ha} / \mathrm{yr}$.
\end{abstract}

Keywords: agricultural land, land use, sectoral policies, cadastral records, statistical data, CORINE

\section{INTRODUCTION}

B\&H has gone through several stages of socio-economic development and each one of them has left its mark on the management and use of agricultural land (from uncontrolled development of village to the II World War, the agrarian reforms, vigorous industrial development until the 1980s, economic stagnation in the eighties, wartime period in the nineties, the post-war period of reconstruction and transition, and finally the period of EU accession policies).

\footnotetext{
${ }^{1}$ Melisa LJUŠA*(corresponding author: melisa.ljusa@gmail.com), Hamid ČUSTOVIĆ, University of Sarajevo, Faculty of Agricultural and Food Sciences, Zmaja od Bosne 8, 71000 Sarajevo, BOSNIA AND HERZEGOVINA.

Notes: The authors declare that they have no conflicts of interest. Authorship Form signed online.
} 
Following World War II the foundations of industrial development of B\&H were laid. Federal plans assigned B\&H the role of producer of raw materials and energy (Bilandžić, 2003). B\&H made a distinct economic growth and became, according to the European standards in the 80s of the last century, an industrialized developing country. Rapid development of industry had considerable consequences that are reflected in permanent and temporary loss of the highest quality of agricultural land in $\mathrm{B} \& \mathrm{H}$, demographic change as well as deagrarization of rural area. Agricultural land had a limited value in terms of economic development of $\mathrm{B} \& \mathrm{H}$ as evidenced by the share of agriculture in gross domestic product of the overall economy of B\&H that was reduced from $26.66 \%$ in 1960 to $14.04 \%$ in 1990. Industrial development put agriculture on the back burner. In the eighties, plans were prepared to develop agriculture and introduce planning and protection of land. However, these plans were never fully implemented, firstly because of the economic crisis and secondly because of the collapse of the former Yugoslavia.

For $\mathrm{B} \& \mathrm{H}$, the new historical era began in 1992 when it became an independent country. The war in B\&H and the post-war reconstruction have resulted in major changes to the land that are reflected in the permanent loss of land, change of its use as well as in the land market (Čustović et al., 2013). One of the main causes of these changes is the migration (internal and international) of around 2.2 million people, particularly from rural to urban areas. These negative trends are still present.

Existing sources of data on land are often old, uncoordinated and irrelevant. Official data on changes in agricultural land is not available and the researches and professional and scientific literature are obviously still using data on the linear loss of agricultural land of 3,000 hectares annually which, according to the available literature, has been in use since 1977 (Resulović, 1977-2010).

The aim of this paper is to use available data to analyze trends and characteristics of the way of use of agricultural land in B\&H as well as the position and sustainable management of agricultural land within the socioeconomic development of the country from the standpoint of impact of sectoral policies, social, political and economic factors in the period from 1961 to date.

\section{MATERIAL AND METHODS}

The two main sources of data on land until 1991 in B\&H were the register (cadaster) of the Republic Geodetic Administration of B\&H and the Republic Institute of Statistics. This study analyzes statistical data on agricultural areas by category of use (1961-1991) and data on arable land by the method of use (19641991). When it comes to cadastral data, the analysis encompassed data for the period 1973-1983 and the year 1991, since there is no integrated data for B\&H for the period 1983-1991.

To analyze changes to agricultural land ( $>5 \mathrm{ha}$ ) in the period 2000-2018, the CORINE (COoRdination of INformation on the Environment) data were used. CORINE is considered to be unique and currently relevant database of 
changes to land in B\&H (Taletović et al., 2010). The basic principles applied to the interpretation of satellite images were the identification of changes with the following characteristics: to be larger than 5 hectares and wider than $100 \mathrm{~m}$; to have occurred in the period 2000-2006, 2006-2012 and 2012-2018; and to be visible on the satellite image regardless of their position. To determine classes of land cover, the standard CORINE nomenclature grouped in three levels was used.

In addition to statistical data on the land, we also used statistical indicators of socio-economic development and data of the population census.

\section{RESULTS AND DISCUSSION \\ Socio-economic development and agricultural land use and management before 1992}

Although agricultural land accounts for nearly $50 \%$ of the total territory, $\mathrm{B} \& \mathrm{H}$ is not rich in high quality agricultural land (Čustović \& Bajramović, 2008). The first three soil bonity category account for only $14.03 \%$, and combined with the soil of IV category their participation amounts to $30.87 \%$ (Čustović, 2005).

Analysis of statistical data (1961-1991) indicate that the total agricultural land area decreased by 101,222 ha or 3,374.06 ha/year. The analysis shows that the reduction in agricultural areas has no linear character and ranges from a reduction of 148 ha, as recorded in 1977, to a reduction of as much as 51,000 ha as recorded in 1982. Within arable land, cropland and gardens were reduced by 207,823 ha and this category of use had a continuing decreasing trend in the observed period. In all the categories (arable land and gardens, orchards, vineyards, meadows, pastures) there were notable oscillations in areas by years, whether it be on the reduction or increase of the area (Chart 1). Additionally, in some years, changes in individual categories were not observed. Within arable land, the total increase in the area of orchards in the observed period is 27,279.00 ha, vineyards 479 ha, while meadows were increased by 59,605 ha. Meadows area was mostly increased at the expense of cropland, as cereal crops growing was in decline.

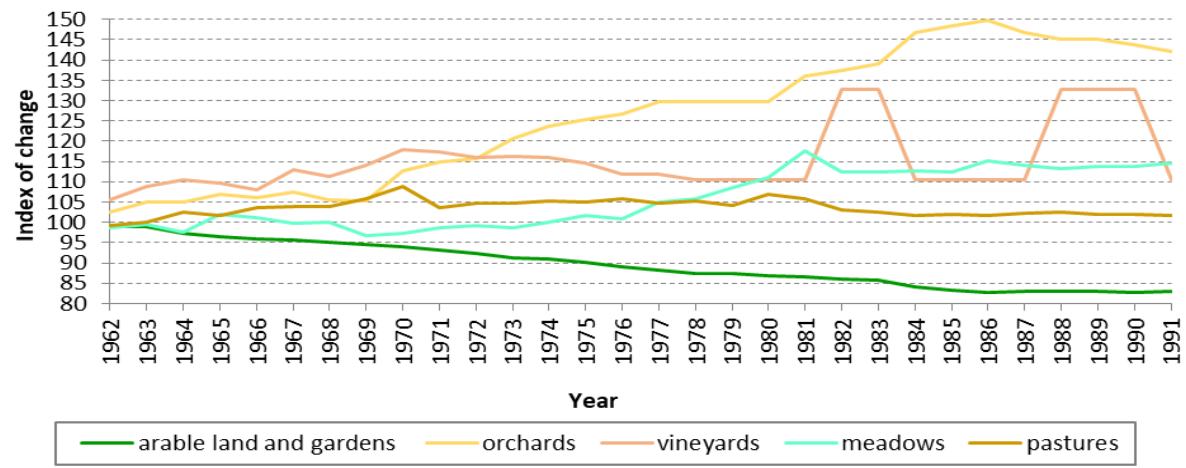

Chart 1. Index of change in agricultural areas by land use categories $1961=100$ 
According to cadastral records, in the period 1973-1991, there is a noticeable reduction in total agricultural land area of 58,186.11 ha or 3,232.56 ha/year; out of that, $96.55 \%$ of total change was recorded in privately owned land. Reduction of agricultural land also has no linear character and by individual years it ranges from 2,318.99 ha (1977) to $13,739.32$ ha (1983). In the period 1973-1991, cropland and garden areas were reduced by 62,931 ha. Cadastral records show that infertile land areas increased by 30,238 ha in the period 19731991.

This research has identified considerable differences between the cadastral data and statistics. For instance, according to the cadastral data, the total area of agricultural land in B\&H in 1973 was bigger by 19,258.19 ha compared to the statistical ones, and in 1981 smaller by as much as 63,909.94 ha. According to the cadaster data in relation to the statistics, in 1973 the area was bigger by 40,594.17 ha in arable land and gardens, by 3,210.48 ha in orchards and by $31,819.14$ ha in meadows. On the other hand, the areas under vineyards were decreased by 948.71 ha as well as pastures by $49,933.31$ ha in cadastral records compared to the statistical ones.

This discrepancy in the data can be attributed to different methodology of data collection, the difference in areas between two surveys, the issue of divergent data within the very municipalities which submitted them to the Geodetic Administration and Institute of Statistics, the failure to update cadastral records contributed to by illegal construction (Ljuša, 2015) as well as the inappropriate taxation policy (Lukić et al., 1991). In the comparative data analysis, the biggest difference is observed in the category of pastures (Chart 2.).

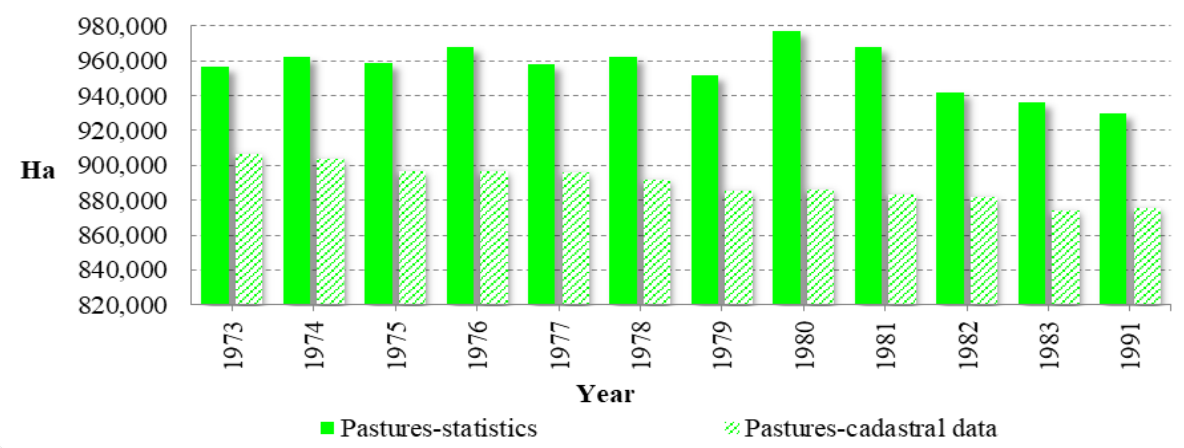

Chart 2. Comparative overview of data-pastures (1973-1991)

This can be attributed to errors in the keeping of records of agricultural, forest and barren land as well as the issue of delimitation of agricultural and forest land that has never been resolved in practice, which led to the situation where one area is recorded both as agricultural (by farmers) and forest (by foresters) at the same time (Ljuša, 2015).

Statistics show that the area of uncultivated arable land and gardens was increasing. Their surface increased from 54,283 ha in 1961 to 160,000 ha as it 
was recorded in 1991. This effect was contributed by deagrarization of the area where the share of farmers in total population in 1991 compared to 1961 was reduced by $74.89 \%$.

The favoring of industry pushed agriculture to the margins and society left agricultural land to its irrational use just because of economic relations between industry and agriculture, that is the preconception that agriculture "provides" very little (Milojevic, 1983). As Bogunović, 1983; Stefanović, 1983; Golić, 1994 reported, the bad position of land in that socio-economic development of B\&H is partly a result of the discrepancy between spatial and economic planning. The problem of the implementation of the policy of physical planning is also connected with the lack of land policy and hence to the related establishment of adequate value of agricultural and forest land, the lack of a permanent spatial planning system and appropriate organization of municipal services (for the implementation and monitoring), the lack of continuous scientific and research work, systemic solution in the area of education of personnel and the like (Bublin, 2000). Negligence towards land has led to the situation where B\&H has around 20,000 ha of environmental (technogenic) deposols and deserts (Resulović, 1999). The stagnation of agriculture resulted in B\&H having difficulties to produce about $50 \%$ of its own food requirements (Selak, 1996).

Given the state of land resources and general negligence towards them, in the late seventies a social commitment was made to make the planning, protection and rational use of agricultural land a fundamental factor of the development of the B\&H agro-industrial complex as evidenced by the five-year socio-economic plans. The need to protect agricultural land arose from the fact that the "Spatial Plan of the Socialist Republic of B\&H for the period from 1981 to 2000" foresaw the requirement of around 100,000 ha of land for the construction at the expense of agricultural land.

The five-year social development plans indicate a positive turn when it comes to agricultural and land policies. Thus the "B\&H Social Plan for the period from 1981 to 1985" outlined an orientation toward more rational land use as well as land development through agro hydro-melioration, land consolidation and redistribution of holdings. The problems of small holdings were recognized as a major constraint in agricultural production (average household had 3.3 ha of agricultural land of which 2 ha were more extensively used). Given the tendency of constant decrease in arable land areas or increase in the area of uncultivated arable land, specific actions were taken to cultivate those agricultural areas that were left fallow (94.000 ha in 1981) in order for them to be completely cultivated in 1985. Also, it was planned to reduce the uncultivated arable land areas (185.000 ha in 1981) down to 92,000 ha. In addition, the Social Plan provided for the land consolidation of 60,000 ha.

However, it is unknown how many of the planned activities in the area of planning and protection of land were actually realized. Only the data on implementation of land consolidation is available. It was carried out on a total area of 64,907 ha in seven municipalities, and the process has only recently been 
administratively completed in some municipalities. Čustović \& Ljuša (2006) reported problems in the implementation of land consolidation which, for example, were related to the lack of incentives for the development of agriculture, slow work of cadastral and geodetic offices in the municipalities, the lack of comprehensive soil maps, etc.

The analyzed data show that the implementation of five-year plans and programs did not yield desired results. In 1986, instead of 92,000 ha that were projected in the plans, the area of uncultivated arable land and gardens amounted to 160,000 ha. In the period 1986-1991, total agricultural areas were reduced by 2,000 ha, while arable land areas were reduced by 4,000 ha. Agricultural land continued to decrease although to a much lesser extent relative to the previous years of the studied period. Sowing area in period 1986-1991 decreased by 22,000 ha instead of the planned and expected increase. Uncultivated fields and gardens were increased by 30,000 ha in the same period of time. It has to be noted that deep economic crisis that struck the former Yugoslavia at that time certainly had an impact on investments in the agricultural sector.

\section{Socio-economic development and agricultural land use and management after 1992}

The agricultural sector, like all other sectors, suffered enormous damage during the war, which according to a study by GTZ (2001) to $\$ 4.5$ billion. The programs of reconstruction and restoration of international donors were more focused on supporting the local population rather than making serious investments in the revitalization of agriculture (Ivanković et al., 2006).

According to Nurković (2012), in the period 1991-2010 the number and share of urban population in the total population of B\&H increased to $46.4 \%$, while the number of residents in rural areas decreased from $75.3 \%$ to $44.2 \%$. By comparing data from the 1991 Census and the preliminary data from the 2013 Census, a large demographic drain was identified in some areas of B\&H. Many rural municipalities have experienced extraordinary changes, such as Glamoč which now has 4,038 inhabitants, which is only $32 \%$ of the total population in 1991 when it amounted 12,593, or Srebrenica municipality whose current population is only $41.56 \%$ of the pre-war one. In the area of East Bosnia, the number of inhabitants is almost halved. It is the movement of the population (over 2.2 million) that led to the occurrence of derelict and permanently lost agricultural land which, according to Čustović et al. (2013), are two basic phenomena when it comes to the way of use of agricultural land in $\mathrm{B} \& \mathrm{H}$ in the postwar period.

CORINE data show that in the period 2000-2018 in B\&H changes occurred on a total area of 71,957 ha. The period of 1991-2000 was a period of stagnation and small activities so the changes in this period can be attributed to natural processes related mainly to succession in abandoned areas. Three characteristic changes within the agricultural areas were identified: increase, decrease and transition of one agricultural class into another (Ljuša, 2015). In the 
period 2000-2018, the increase in agricultural areas amounts to 3,137 ha (eg. class 311 (broad-leaved forest) converted to 243 (land principally occupied by agriculture, with significant areas of natural vegetation class)), decrease to 14,152 ha (eg. class 211 (non-irrigated arable land) converted to 112 (discontinuous urban fabric)), while 6,235 ha transitioned from one agricultural class into another (eg. class 231 (pastures) converted to 242 (complex cultivation patterns)). Trends of change in the three observed periods (2000-2006, 2006-2012, 2012-2018) are different (Chart 3.). In the period 20002006, agricultural land areas increased by 554 ha, decreased by 9,327 ha, while the transition from one to another agricultural class was recorded on an area of 4,572 ha. In the period 2006-2012, agricultural land areas increased by 1,548 ha, the reduction amounted to 1,997 ha, while the transition from one into another agricultural class was recorded on an area of 1,244 ha. In the period 2012-2018, agricultural land areas increased by 1,035 ha, the reduction amounted to 2,829 ha, while the transition from one into another agricultural class was recorded on an area of 421 ha.

\begin{tabular}{|c|c|c|c|}
\hline \\
\hline \multicolumn{4}{|l|}{$\begin{array}{r}100 \% \\
80 \%\end{array}$} \\
\hline $60 \%$ & & & \\
\hline $40 \%$ & & & \\
\hline $20 \%$ & & & \\
\hline $0 \%$ & $2000-2006$ & $2006-2012$ & $2012-2018$ \\
\hline $\begin{array}{c}\text { Transition from one to } \\
\text { another a griculturalclass }\end{array}$ & 4.571 & 1.243 & 421 \\
\hline $\begin{array}{c}\text { Increase of a gricultural } \\
\text { a reas }\end{array}$ & 554 & 1.548 & 1.035 \\
\hline $\begin{array}{c}\text { Decrea se of a gricultural } \\
\text { areas }\end{array}$ & 9.326 & 1.997 & 2.829 \\
\hline
\end{tabular}

Chart 3. Comparative overview of changes in agricultural areas (2000-2018)

In the context of conversion of agricultural areas in artificial surfaces, the largest areas $(6,099.4 \mathrm{ha})$ were turned into discontinuous urban areas, where 98.3\% of these changes occurred in the period 2000-2006. Agricultural areas were also converted into industrial and business areas, 340.59 ha (2000-2006), 146.61 ha (2006-2012) and 78.6 ha (2012-2018) respectively. However total conversion of agricultural areas in artificial surfaces is 7,450 ha which is 414 ha/year.

Mines and mineral resources exploitation sites occupy a considerable area covering 8,072.18 ha. In the period 2000-2006, these areas were increased by $653.72 \mathrm{ha}$, in the period 2006-2012 by 718.11 ha and in period 2012-2018 by 808.6 ha.

What stands out as a particular problem, in addition to the use of agricultural land for non-agricultural purposes, is the emergence of derelict land and transition of land in the succession of forest vegetation. According to the 
CORINE data (2000-2018), 2,590 ha of agricultural land, mostly pastures (853.79 ha), were converted into the succession of forest vegetation.

However, CORINE has limitations when it comes to the identification of derelict land due to the adopted methodology (mapping of changes $>5 \mathrm{ha}$ ) and small scale of 1:100.000. For this reason many of the permanently lost areas $<5$ ha could not be included in the CORINE database. For example, in the municipalities of Kalesija and Gradacac, in the period 2008-2012 (M 1:10000) succession was identified in an area of 374.18 ha, and 355.76 ha respectively (Čustović et al., 2013a; Čustović et al., 2013b).

Statistical data indicate that the lack of a clear vision of development of agrarian and land policies in the country, lack of investments and incentives, fragmentation of the holdings as well as numerous other problems along with large deagrarization resulted in having over $50 \%$ of arable land uncultivated. The share of agricultural in the total population decreased to just $20.4 \%$ which means that every fifth or sixth person is engaged in agriculture.

Just like in the previous period before 1991, spatial planning nowadays is not adequately coordinated with the plans of social and economic development. There is a very pronounced problem of illegal construction, its sanctioning and the general lack of monitoring such processes. The pressure of development on the best quality agricultural land is best illustrated by the example of Kalesija municipality where the biggest expansion of the built-up areas and settlements occurred within the legally protected rating categories of land of IVb (86 ha or $47 \%$ of total change) and III rating category of high-quality land (49 ha or $27 \%$ of total change) in period 2008-2012 (Ljuša et al., 2016). Also significant occurrence of succession of agricultural areas amounting to 374.18 ha were identified in Kalesija in the period 2008-2012.

The cause of the poor state of land management/use can be sought in the absence of land market or its very weak position which is particularly contributed to by the lack of land registers that were hidden or destroyed during the war, or the inability to prove ownership, which opens the door to opportunities for illegal acquisition of wealth and corruption (Čustović et al., 2013). Lack of soil classes maps and updated information about the land and its quality creates room for speculation and manipulation of this resource in the context of conversion into construction land.

Land consolidation has not been enforced. It is evident that B\&H is significantly behind schedule in terms of implementing the reforms. The lack of consensus on the long-term socio-economic development, agriculture and rural policies, information systems, database of land resources, basic strategic documents etc., contributes to the fact that the agricultural sector is considered the least regulated.

\section{CONCLUSIONS}

Through the analysis of three sets of data on agricultural land, the study has shown that the average loss of agricultural land is not linear (3,000 ha/year) 
and that there are huge fluctuations in the change of use in all its categories. Studies have shown that there is a strong correlation between land use and socioeconomic development policy which in all sectors, including agriculture, was based on the planned economic policy. Land policy was implemented within this framework with more or less success. With the current problems of deagrarization, ineffective agrarian and land policies and incentives, it is very unlikely to expect the area of uncultivated fields to reduce; on the contrary, it is going to grow and partly become affected by the processes of succession and degradation, especially in marginalized areas and fragmented holdings. Without making a decisive shift in policies and having clearly defined objectives aimed at protecting the agricultural areas and putting them in use, it is hard to expect any significant changes in the sector. Land consolidation whose significance has not been recognized could be the solution to many problems in the agricultural sector and rural planning in $\mathrm{B} \& \mathrm{H}$.

\section{REFERENCES}

Begić K. (2000). Ekonomska politika: Uvod u ekonomsku politiku: opća pitanja ekonomske politike. Sarajevo.

Bogunović S. (1983). Osnovni preduslov za planiranje skladnijeg i racionalnijeg ukupnog društvenog razvoja. Radovi, broj 9, Institut za arhitekturu, urbanizam i prostorno planiranje Arhitektonskog fakulteta u Sarajevu. Sarajevo.

Bilandžić D. (2003). Zlatno doba Bosne i Hercegovine. Naučni skup: Bosna i Hercegovina prije i nakon ZAVNOBiH-a, Posebna izdanja, Knjiga 37. Akademija nauka i umjetnosti Bosne i Hercegovine. Sarajevo.

Bublin M. (2000). Prostorno planiranje. Univerzitetska knjiga, Studentska stamparija Univerziteta. Sarajevo.

Čustović H. (2005). An overview of general Land and Soil Water conditions in Bosnia and Herzegovina. European Soil Bureau-Research Report No. 9., JRC.

Čustović H., Ljuša M. (2006). Participatory Land Use Development in Bosnia and Herzegovina. International Conference on Land Consolidation and Land Development. FAO. Prague.

Čustović, H., Ljuša, M., Marković, M. (2013). Land use changes and loss of soil in Bosnia and Herzegovina as consequences of the war and socio-economic transition. $2^{\text {nd }}$ Scientific Conference UNCCD. Bon.

Čustović H., Ljuša M. i drugi. (2013a). Studija upotrebne vrijednosti zemljišta za područje općine Kalesija.

Čustović H., Ljuša M. i drugi. (2013b). Studija upotrebne vrijednosti zemljišta za područje općine Gradačac.

Čustović, H.; Bajramović, S. (2008). State-owned land as a potential factor of improvement of ownership structure in BiH. Works Of The Faculty Of Agriculture University Of Sarajevo: 59(1), 219-231.

Golić B. (1994). Ekonomika prostora u privrednom razvoju Bosne i Hercegovine. Bosna public. Sarajevo.

GTZ (2001). Studija o razvoju prehrambene industrije u Bosni i Hercegovini. Sarajevo.

Ivanković M., Bojnec S., Kolega A., Selak V. (2006). Ekonomska i drustvena uloga poljoprivrede u Federaciji Bosne i Hercegovine. Journal for General Social Issues. Vol.15 No.4-5 (84-85) 01/2006. 
Lukić V., Begić M., Imamović J. (1991). Teorijski i prakticni komentar Zakona o premjeru i katastru nekretnina. YU ISBN 86-901233-1-8. SID „STRUKA“. Sarajevo.

Ljuša M., Čustović H., Cero M. (2016). Land capability study and map in function of land protection, spatial planning and agro-ecological zoning. In print.

Ljuša M. (2015). Trendovi i karakteristike promjena načina korištenja poljoprivrednog zemljišta u Bosni i Hercegovini. Disertacija. Univerzitet u Sarajevu.

Milojević A. (1983). Selo, poljoprivreda i poljoprivredno zemljište. Savjetovanje o temi Zemljište u Prostornom planu SR BiH, referati. Poljoprivredni fakultet Sarajevo. Sarajevo.

Nurković R. (2012). Urbanization and rural development in Bosnia and Herzegovina. UGI 2011. Regional Geographic Conference, Santiago Chile, 26 Local Development. Santiago Chile.

Resulović H. (1977). Uticaj tehnološkog progresa na proces oštećenja i potrošnje zemljišta. Poljoprivredni fakultet Sarajevo. Sarajevo.

Resulović H. (1978). Poljoprivredna zemljišta SR Bosne i Hercegovine (s aspekta njihove rasprostranjenosti, upotrebne vrijednosti i potrošnje izvan sfere poljoprivrede. Sarajevo.

Resulović H. (1983). Gubici i degradacija poljoprivrednog zemljišta u SR BiH. Savjetovanje o temi „Zemljište u Prostornom planu SR BiH“, referati. Poljoprivredni fakultet Sarajevo. Sarajevo.

Resulović H. (1993). Oštećenja zemljišta izazvana ratnim dejstvima na teritoriji Republike Bosne i Hercegovine. Studija. Zavod za agropedologiju. Sarajevo.

Resulović H. (1999). Zemljišni resursi u Bosni i Hercegovini-korištenje u funkciji održivog razvoja. Posebna izdanja, Knjiga 16. Akademija nauka i umjetnosti Bosne i Hercegovine. Sarajevo.

Resulović H., Bukalo E., Kraišnik V. (2010). Načini korištenja zemljišta-suprotnosti i mogućnosti harmonizacije u funkciji održivog razvoja. Prvi naučni simpozijum agronoma sa međunarodnim učešćem-Agrosym. Jahorina.

Selak V. (1996). Tehničko-tehnološki aspekti strategije razvoja poljoprivrede R/F BiH. Prvo savjetovanje: Strategija razvoja poljoprivrede, Bihać, 10-11 maj 1996. godine.

Stefanović V. (1983). Ocjena realnosti, primjenljivosti i racionalnosti društvenoekonomskih planova razvoja bez prostorne komponente. Radovi, broj 9, Institut za arhitekturu, urbanizam i prostorno planiranje Arhitektonskog fakulteta u Sarajevu. Studentski servis. Sarajevo.

Taletović J., Ljuša M., Đuzo F., Vojniković S., Čustović H. (2010). Priprema baze podataka o zemljišnom pokrivaču CORINE 2006-metodološki pristup i osnovni principi, Zbornik radova XXI Međunarodna naučno-stručna konferencija poljoprivrede i prehrambene industrije, Neum, str. 637-645. 